Article

\title{
Biological Control of the Weed Hemp Sesbania (Sesbania exaltata) in Rice (Oryza sativa) by the Fungus Myrothecium verrucaria
}

\author{
Clyde D. Boyette $^{1, *}$, Robert E. Hoagland ${ }^{2}$ and Kenneth C. Stetina ${ }^{1}$
}

1 USDA-ARS, Biological Control of Pests Research Unit, Stoneville, MS, 38776, USA;

E-Mail: kenneth.stetina@ars.usda.gov

2 USDA-ARS, Crop Production Systems Research Unit, Stoneville, MS, 38776, USA;

E-Mail: bob.hoagland@ars.usda.gov

* Author to whom correspondence should be addressed; E-Mail: doug.boyette@ars.usda.gov;

Tel.: +1-662-686-5217; Fax: +1-662-686-5281.

Received: 17 October 2013; in revised form: 7 November 2013 / Accepted: 17 January 2014 /

Published: 27 January 2014

\begin{abstract}
In greenhouse and field experiments, a mycelial formulation of the fungus Myrothecium verrucaria (IMI 361690) containing 0.20\% Silwet L-77 surfactant exhibited high bioherbicidal efficacy against the problematic weed hemp sesbania. Infection and mortality levels of $100 \%$ of hemp sesbania seedlings occurred within $48 \mathrm{~h}$ after fungal application in the greenhouse. In rice field tests conducted over a three year period, $M$. verrucaria at an inoculum concentration of $50 \mathrm{~g} \mathrm{~L}^{-1}$ (dry mycelium equivalent) controlled $95 \%$ of $\leq 20 \mathrm{~cm}$ tall hemp sesbania plants. $M$. verrucaria also controlled larger plants ( $\geq 60 \mathrm{~cm}$ tall) using this high inoculum concentration. This level of weed control, as well as rice yields from plots where weeds were effectively controlled, were similar to those which occurred with the herbicide acifluorfen. These results suggest that a mycelial formulation of $M$. verrucaria has potential as a bioherbicide for controlling hemp sesbania in rice.
\end{abstract}

Keywords: bioherbicide; biocontrol; hemp sesbania; Myrothecium verrucaria; mycelial formulation 


\section{Introduction}

Hemp sesbania [Sesbania exaltata (Rydb.) ex. A.W. Hill] is an aggressive, annual, nodulating leguminous weed that infests rice (Oryza sativa L.), soybean [Glycine max (L.) Merr.], cotton (Gossypium hirsutum L.) and sunflower (Helianthus annuus L.) [1]. This plant is distributed in the U.S. coastal plain of Virginia to Florida to Texas in ditches, on stream banks, fallow fields and waste places [2] and has been rated as one of the 10 most troublesome weeds in Arkansas, Louisiana, and Mississippi [3]. It can attain a height of $3 \mathrm{~m}$ at maturity [4], produce abundant seeds $(21,000$ seeds per plant) [5] and reduce crop yield via shading and competition [6,7]. During rice production, it can interfere with harvesting operations, since its fibrous and woody stem biomass can damage combine blades, thereby lengthening harvest time and increasing harvesting and grain drying costs. Contamination by the black hemp sesbania seeds in harvested rice grain also lowers grain quality and value of the crop [5]. This weed is also problematic in sunflower, resulting in 35\% yield reduction when competing with sunflower for the entire growing season [1].

Hemp sesbania is toxic to livestock and humans, and seeds appear to be the most toxic plant part [2]. Cattle can die from ingesting this weed and symptoms include hemorrhagic diarrhea, constipation, reduced respiration and elevated pulse rate. They become prostrate and comatose before death. An opened rumen may reveal sprouted seeds and a hemorrhagic inflammation of the abomasum and intestines [8].

Hemp sesbania can add nitrogen into soils through the nodulation process. Beneficial aspects of a related plant, Sesbania rostrata Brem., have been evaluated as a green manure for lowland rice in Sierra Leone [9] and in the Philippines [10], resulting in significant rice yield increases when used in a rotation program with rice.

Single or multiple applications of herbicides to control using hemp sesbania have been intensely evaluated, showing that some herbicide treatments can provide effective control. Table 1 lists the common and chemical names of herbicides cited in this paper. For example, both acifluorfen and fomesafen effectively controlled hemp sesbania [11]. Minimum effective rates of acifluorfen or fomesafen to provide 80 and $100 \%$ control of 50 - to $60-\mathrm{cm}$ tall hemp sesbania in soybeans were 50 and $140 \mathrm{~g} \mathrm{ha}^{-1}$, respectively [12]. Lactofen effectively controlled hemp sesbania without the addition of glyphosate, and acifluorfen and chlorimuron combined with glyphosate reduced hemp sesbania fresh weight nearly two-fold more than glyphosate alone [13].

Rice yields are improved when hemp sesbania is effectively controlled. For example, rice grain yields were higher with herbicides that increased control of hemp sesbania, including bentazon plus acifluorfen, carfentrazone and halosulfuron, compared to yields in plots treated with imazethapyr plus bensulfuron or triclopyr mixtures $[14,15]$.

Hemp sesbania has been reported to have tolerance to glyphosate $[16,17,18]$. Glyphosate alone controlled hemp sesbania by only $28 \%$ and $45 \%$ at rates of 0.84 and $1.12 \mathrm{~kg}$ active ingredient (ai) ha ${ }^{-1}$, respectively [11]. Other reports indicate that single applications of glyphosate are not adequate to control hemp sesbania [19,20,21]. Several pre-emergence herbicides at half or full rates followed by glyphosate did not completely control hemp sesbania in soybeans, necessitating an acifluorfen application [22]. However, some herbicides or tank mixtures of certain herbicides with glyphosate increased hemp sesbania control [11]. 
Table 1. Common and chemical names of herbicides mentioned in text [23].

\begin{tabular}{|c|c|}
\hline $\begin{array}{l}\text { Common } \\
\text { Name }\end{array}$ & Chemical Name \\
\hline Acifluorfen & 5-[2-chloro-4-(trifluoromethyl)phenoxy]-2-nitrobenzoic acid \\
\hline Bensulfuron & $\begin{array}{l}\text { 2-[[[[[(4,6-dimethoxy-2-pyrimidinyl)amino] carbonyl]amino }] \text { sulfonyl }] \text { methyl] } \\
\text { benzoic acid }\end{array}$ \\
\hline Bentazon & 3-(1-methylethyl)-(1H)-2,1,3-benzothiadiazin-4(3H)-one 2,2-dioxide \\
\hline Carfentrazone & $\begin{array}{l}\alpha, 2 \text {-dichloro-5-[4-(difluoromethyl)-4,5-dihydro-3-methyl-5-oxo-1H-1,2,4-triazol-1-yl] } \\
\text {-4-fluorobenzenepropanoic acid }\end{array}$ \\
\hline Chlorimuron & 2-[[[[(4-chloro-6-methoxy-2-pyrimidinyl)amino]carbonyl]amino]sulfonyl $]$ benzoic acid \\
\hline Fomesafen & 5-[2-chloro-4-(trifluoromethyl)phenoxy]- $N$-(methylsulfonyl)-2-nitrobenzamide \\
\hline Glyphosate & $N$-(phosphonomethyl)glycine \\
\hline Halosulfuron & $\begin{array}{l}\text { Methyl 5-[((4,6-dimethoxy-2-pyrimidinyl)amino)carbonylamino-sulfonyl]-3-chloro- } \\
\text { 1-methyl-1H-pyrazole-4-carboxylate }\end{array}$ \\
\hline Imazapyr & $\begin{array}{l}( \pm) \text {-2-[4,5-dihydro-4-methyl-4-(1-methylethyl)-5-oxo- } 1 H \text {-imidazol-2-yl]-3- } \\
\text { pyridinecarboxylic acid }\end{array}$ \\
\hline Imazethapyr & $\begin{array}{l}\text { 2-(4,5-dihydro-4-methyl-4-(1-methylethyl)-5-oxo-1H-imidazol-2-yl)-5-ethyl-3- } \\
\text { pyridine-carboxylic acid }\end{array}$ \\
\hline Lactofen & $\begin{array}{l}( \pm) \text {-2-ethoxy-1-methyl-2-oxoethyl-5-[2-chloro-4-(trifluoro-methyl)phenoxy]-2- } \\
\text { nitrobenzoate }\end{array}$ \\
\hline Pendimethalin & $N$-(1-ethylpropyl)-3,4-dimethyl-2,6-dinitrobenzenamine \\
\hline Triclopyr & {$[(3,5,6$-trichloro-2-pyridinyl)oxy]acetic acid } \\
\hline
\end{tabular}

Although herbicides are the most effective and immediate solution to weed control, other solutions, including biological control (e.g., bioherbicides) are becoming available [24]. The use of bioherbicides has been recognized as a potential technological alternative to chemical herbicides in certain situations [25-28]. Global interest exists in the bioherbicide concept, and active research and development projects by commercial entities have been established in the USA, Canada, Europe, Australia, Japan, and other countries [26-29].

Several different fungal pathogens have been shown to possess biological control potential of this weed. For example, spore mixtures of Alternaria crassa (Sacc.) Rands, with either plant filtrates or fruit pectin, infected and killed hemp sesbania seedlings [30]. The fungus Colletotrichum truncatum (Schw.) Andrus and Moore has shown bioherbicidal potential for controlling hemp sesbania [31-34]. Colletotrichum gloeosporioides f. sp. aeschynomene (Penz) Sacc. (COLLEGO ${ }^{\mathrm{TM}}$, Encore Technologies, 
Inc., Minnkota, MN, USA; presently marketed as LockDown ${ }^{\circledR}$ [35]), registered for northern jointvetch [Aeschynomene virginica (L.) B.S.P] control [36] effectively controlled hemp sesbania in rice when formulated in an invert emulsion [37,38].

The fungus Myrothecium verrucaria (Alb. and Schwein.) Ditmar:Fr. (strain IMI 361690) has been extensively evaluated as a bioherbicide for several weeds. M. verrucaria has exhibited bioherbicide activity against various weeds including sicklepod [Senna obtusifolia (L.) H.S. Barneby], kudzu [Pueraria lobata var. montana Willd. (Ohwii.)] [39], and morninglory spp. (Ipomoea spp.) [40], as well as hemp sesbania [41,42], when formulated with the surfactant Silwet L-77. Although $M$. verrucaria can potentially control several weed species, its production of toxic macrocyclic trichothecenes (mycotoxins) by fungal spores [43] is an issue that limits its practical usage. Thus, a biologically effective, mycotoxin-free formulation would greatly expand the bioherbicidal potential of this bioherbicide.

Most fungi that have been evaluated as bioherbicides utilize formulations of fungal spores as the active component [26], but highly effective mycelial bioherbicide formulations of several fungal bioherbicides also have been developed [44-47]. Experiments in our laboratory demonstrated that a spore-free liquid culture of $M$. verrucaria comprised of mycelia fragments was void of trichothecenes, and exhibited high bioherbicidal activity against the weed kudzu under field conditions [48].

Due to the high efficacy exhibited by $M$. verrucaria against several weeds, including hemp sesbania, and because $M$. verrucaria spores had no significant effects on rice seedlings [41], we hypothesized that a mycelial formulation of $M$. verrucaria may have potential for controlling hemp sesbania in a rice cropping situation. Thus, the objectives of this study were to determine if various concentrations of a mycelial formulation of $M$. verrucaria could effectively control hemp sesbania at several different stages of growth in rice under field conditions, and to determine the effects of M. verrucaria on rice yields.

\section{Materials and Methods}

\subsection{Culture, Storage, and Mass Production}

A strain of $M$. verrucaria, originally isolated from diseased sicklepod [41], was used in the present studies. The fungus was sub-cultured on potato dextrose agar (PDA, Difco Laboratories, Detroit, MI, USA) in Petri dishes and stock culture samples were stored on twice-sterilized soil (25\% water holding capacity) at $4{ }^{\circ} \mathrm{C}$ [49]. Inoculated Petri dishes were inverted and placed on open-mesh wire shelves in an incubator (Precision Scientific Inc., Chicago, IL, USA) at $28{ }^{\circ} \mathrm{C}$. The light intensity at dish level was $200 \mu \mathrm{Em}^{-2} \mathrm{~s}^{-1}$ photosynthetically active radiation (PAR).

A soy flour-corn meal liquid medium was used to produce $M$. verrucaria inocula, since it yielded the most efficacious and highest mycelial content of this fungus when several media were compared in experiments involving kudzu [48]. M. verrucaria starter inoculum (500 mL) was grown in 1-L flasks incubated in rotary shakers (185-200 rpm, $28{ }^{\circ} \mathrm{C}$ for 7 days). The above medium was also adopted for scaled-up production in laboratory fermenters (Models MF-214 and CMF-128, New Brunswick Corp., Edison, NJ, USA. Fermentations were conducted at $185-200 \mathrm{rpm}$ and $28^{\circ} \mathrm{C}$ for $48 \mathrm{~h}$. Harvested mycelia batches from the flasks were filtered (\#40 Whatman filter paper) and oven-dried $\left(80^{\circ} \mathrm{C}, 24 \mathrm{~h}\right)$ and dry 
weights were recorded in order to determine mycelia biomass (referred to as dry mycelium equivalents). Efficacy tests on hemp sesbania plants under greenhouse and field conditions utilized the raw fermentation product (liquid, unspent medium, and mycelium). For all experiments, prior to spray application to plants, the fermentation product was homogenized in 3-4 L aliquots with an electric blender (high speed, 3 min, Waring Model CB1043, Springfield, MO, USA). All efficacy tests were repeated twice.

\subsection{Laboratory and Greenhouse Protocols}

Hemp sesbania seeds were obtained from a local seed company (Azlin Seed Co., Leland, MS, USA). Seeds were surface-sterilized $(0.05 \% \mathrm{NaOCl}, 5 \mathrm{~min})$, rinsed with sterile distilled water, and germinated $\left(28{ }^{\circ} \mathrm{C}\right)$ on moistened filter paper in Petri dishes. After germination $(\sim 48 \mathrm{~h})$, seeds were planted in a commercial potting mix (Jiffy-mix; Jiffy Products of America, Batavia, IL, USA) contained in peat strips, with each strip containing 12 plants. The potting mixture was supplemented with a controlled-release (14:14:14, NPK) fertilizer (Osmocote; Grace Sierra Horticultural Products, Milpitas, CA, USA). The plants were placed in sub-irrigated trays in a greenhouse [ 25 to $30{ }^{\circ} \mathrm{C}, 40 \%-90 \%$ relative humidity $(\mathrm{RH})]$. The photoperiod was $14 \mathrm{~h}$, with $1800 \mathrm{PAR}$ as measured at midday with a light meter. Hemp sesbania seedlings were either 10-20, 21-40, or 41-60 cm in height when treated with various concentrations of concentrations of $M$. verrucaria raw fermentation product $[1.0 \times, 0.5 \times$ and $0.1 \times$, where the $1.0 \times$ concentration contained the equivalent of $50.0 \mathrm{~g}$ mycelium (dry weight basis) $\mathrm{L}^{-1}$ ], and the dilutions were achieved using distilled, de-ionized water. The experiment consisted of five treatments (12 plants per treatment): (1) M. verrucaria $(1.0 \times)$ containing $0.2 \%(\mathrm{v} / \mathrm{v})$ Silwet L-77TM surfactant (SW L-77; OSi Specialties, Inc., Danbury, CT, USA); (2) M. verrucaria at $0.5 \times$ containing SW L-77; (3) M. verrucaria at $0.1 \times$ containing SW L-77; (4) SW L-77 alone; and (5) distilled, de-ionized water alone. These treatments were performed in triplicate. Spray application rates delivered about $100 \mathrm{~L} \mathrm{ha}^{-1}$, and were applied with a hand held sprayer (Spray-Tool, Aervoe Industries, Gardnerville, NV, USA). After treatment, seedlings were placed in darkened dew chambers (Model I-36 DL; Percival Sci. Ind., Perry, IA, USA) in the dark at $28{ }^{\circ} \mathrm{C}, 100 \mathrm{RH}$ for $12 \mathrm{~h}$, and then moved to greenhouse benches. Plants were monitored at daily intervals for disease development for 7 days after treatment. Disease severity was based on a visual rating scale (per plant basis) [50] to estimate disease progression. A rating scale of 0 to 10 was used, with 0 being unaffected, and 2, 4, 6, $8=20 \%, 40 \%, 60 \%$, and $80 \%$ leaf and stem lesion coverage/injury, respectively, and $10=$ plant mortality. Percentage control and biomass reductions were determined 7 days after treatment. Plants were excised at the soil line, oven-dried for $48 \mathrm{~h}$ at $85{ }^{\circ} \mathrm{C}$, weighed, and the percentage biomass reduction determined. Treatments were replicated four times, for a total of 48 individual plants per treatment. The experiment was repeated over time, and data were averaged following Bartlett's test for homogeneity of variance [51]. A randomized complete block experimental design was utilized. The mean percentage of plant mortalities and biomass reductions calculated for each treatment were subjected to arc-sin transformation. The transformed data were statistically compared using analysis of variance (ANOVA) at the 5\% probability level. Values are presented as means of replicated experiments. When significant differences were detected by the $F$-test, means were separated with Fisher's protected LSD test at the 0.05 level of 
probability. In the disease kinetic studies, data were analyzed using standard mean errors and best-fit regression analysis.

\subsection{Field Experiment Protocols}

Field experiments were conducted in flooded rice field test plots at Stoneville, MS, USA, in 2006, 2007, and 2009. Pendimethalin at $1.12 \mathrm{~kg}$ ai ha ${ }^{-1}$ was applied pre-emergence for grass weed control. Rice and hemp sesbania were seeded simultaneously, with hemp sesbania seeded at a rate of ca

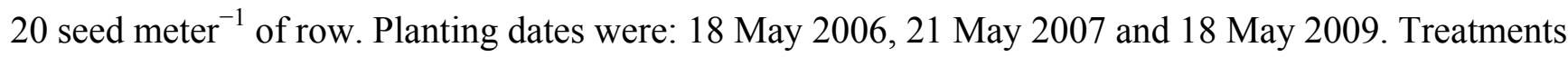
were applied when the hemp sesbania plants were either, 10-20, 21-40, or 41-60 cm in height. Treatment dates for the 10-20 cm plants were 5 June 2006, 26 June 2007 and 18 July 2009. Treatment dates for the 21-40 cm plants were 4 June 2006, 25 June 2007 and 16 July 2009. Treatment dates for the 41-60 cm plants were 8 June 2006, 20 June 2007 and 20 July 2009. The experiment consisted of six treatments: (1) M. verrucaria $(1.0 \times)$ containing SW L-77 $(0.2 \%, \mathrm{v} / \mathrm{v})$; (2) M. verrucaria at $0.5 \times$ containing SW L-77; (3) M. verrucaria at 0.1× containing SW L-77; (4) SW L-77 alone; (5) distilled, de-ionized water alone; and (6) acifluorfen $\left(0.56 \mathrm{~kg}\right.$ a.i. $\left.\mathrm{ha}^{-1}\right)$. Acifluorfen is widely used for controlling hemp sesbania [12]. All spray applications were made with back-pack sprayers (Gilmour, Somerset, PA, USA) at spray volumes of $200 \mathrm{~L} \mathrm{ha}^{-1}$. A quadrant $\left(1.0 \mathrm{~m}^{2}\right)$ was randomly selected in each plot, which contained 15 to 20 hemp sesbania plants. Disease monitoring, weed control percentages and dry weight determinations were made on hemp sesbania plants within the quadrants. Weed control was determined seven days after treatment. Disease of hemp sesbania plants in the 10-20 cm growth stage was monitored at daily intervals over a 7-day period. Disease progression was based on a 0 to 10 rating scale, as described previously. Symptomatology was considered "severe" at ratings of 8-10. A randomized complete block experimental design was utilized and data were averaged over the 3 year testing period, after subjecting to Bartlett's test for homogeneity of variance [51]. Data were analyzed using analysis of variance. The percentage data (hemp sesbania injury/control and biomass reduction) were subjected to arc-sin transformation prior to analysis and treatment means and standard errors of the mean are presented. Values are presented as means of replicated experiments. When significant differences were detected by the $F$-test, means were separated with Fisher's protected LSD test at the 0.05 probability level. In the disease kinetic studies, data were analyzed using standard mean errors and best-fit regression analysis. Rice yields were recorded at the end of the season (September), and only yields from the early-season treatments (10-20 cm hemp sesbania) are presented.

\section{Results and Discussion}

In greenhouse experiments, application of M. verrucaria mycelia $(1.0 \times$ rate $)$ in $0.20 \%$ Silwet L-77 $(\mathrm{v} / \mathrm{v})$ provided $100 \%$ mortality of 10-20 $\mathrm{cm}$ tall hemp sesbania seedlings after 7 days, while inoculum rates of $0.5 \times$ and $0.1 \times$ controlled plants by $85 \%$ and $65 \%$, respectively (Figure $1 \mathrm{~A}$ ). Previous studies showed that the addition of Silwet L-77 was essential to promote infection and control of various weeds by $M$. verrucaria conidial suspensions [41] and mycelial suspensions [48]. Hemp sesbania biomass (dry weights) were also reduced by $100 \%$ at the highest inoculum concentration, with $90 \%$ and $70 \%$ reductions occurring at the $0.5 \times$ and $0.1 \times$ rates, respectively (Figure $1 \mathrm{~A}$ ). No mortality or biomass reduction occurred on hemp sesbania seedlings treated with surfactant in water or with water alone 
(Figure 1A-C). Efficacy of $M$. verrucaria was influenced by the stage of growth of hemp sesbania seedlings in the greenhouse and generally, weeds are more difficult to control with herbicides or bioherbicides as they become older and more mature. In the greenhouse, all M. verrucaria-inoculated hemp sesbania plants (regardless of size) were affected, but the levels of mortality and dry weight reduction decreased as the size of the plants increased above $20 \mathrm{~cm}$ (Figure 1A-C). However, by increasing inoculum concentration, significant increases in mortality and dry weight reduction were achieved (Figure 1A-C).

Figure 1. Effect of Myrothecium verrucaria mycelial concentration on mortality and dry weight reduction of hemp sesbania in greenhouse experiments, seven days after treatment. M. verrucaria mycelia were suspended in $0.20 \%$ (v/v) Silwet L-77 surfactant. $\mathbf{A}=$ hemp sesbania plants at $10-20 \mathrm{~cm}$ in height; $\mathbf{B}=$ hemp sesbania plants at $21-40 \mathrm{~cm}$ in height; and $\mathbf{C}=$ hemp sesbania plants at $41-60 \mathrm{~cm}$ in height. Histogram bar values for each parameter with the same letter are not significantly different at $p=0.05$ using Fisher's least significant difference.

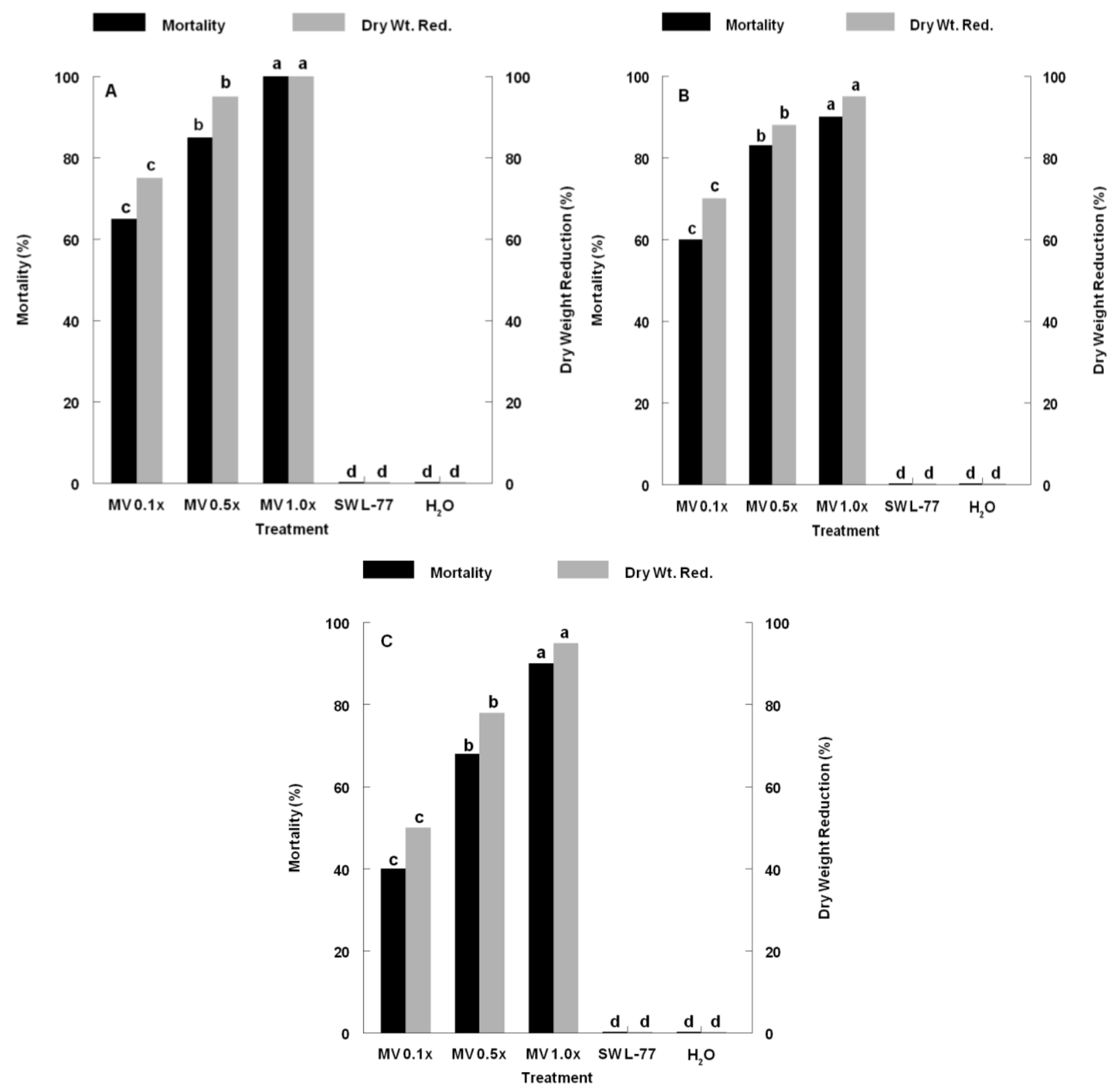


In disease kinetic studies under greenhouse conditions, disease progressed rapidly in plants treated with the highest inoculum rate $(1.0 \times)$, with a 9.5 disease rating occurring after only 1 day (Figure 2). Disease progressed at a slower rate at lower inoculum concentrations, requiring 6 days to achieve disease ratings of 6.5 and 8.5 , respectively, for the $0.1 \times$ and $0.5 \times$ inoculum concentrations under greenhouse conditions (Figure 2). Disease progression of infected hemp sesbania was similar to that incited by $M$. verrucaria on infected kudzu [48], and morningglories [40] in bioherbicidal studies of those weeds under greenhouse conditions.

Figure 2. Disease progression of 10-20 cm tall hemp sesbania incited by Myrothecium verrucaria mycelia on hemp sesbania in the greenhouse. Disease severity was based on a visual rating scale (per plant basis) [50] to estimate disease progression. A rating scale of 0 to 10 was used, as described in the Materials and Methods section. Symptomatology was considered "severe" at ratings of 8-10. The relationships for $M$. verrucaria disease progression are best described by the equations: $Y=2.67+3.76 X-0.41 X^{2}, R^{2}=0.72$ (solid spheres, solid line) for $M$. verrucaria applied at an inoculum rate of $1.0 \times ; Y=0.36+2.17-$ $0.15 X^{2}, R^{2}=0.98$ (solid triangles, dashed line) for $M$. verrucaria applied at an inoculum rate of $0.5 \times ; Y=0.65+1.07-0.03 X^{2}, R^{2}=0.92$ (solid squares, dotted line) for $M$. verrucaria applied at an inoculum rate of $0.1 \times$. Error bars $= \pm 1$ SEM.

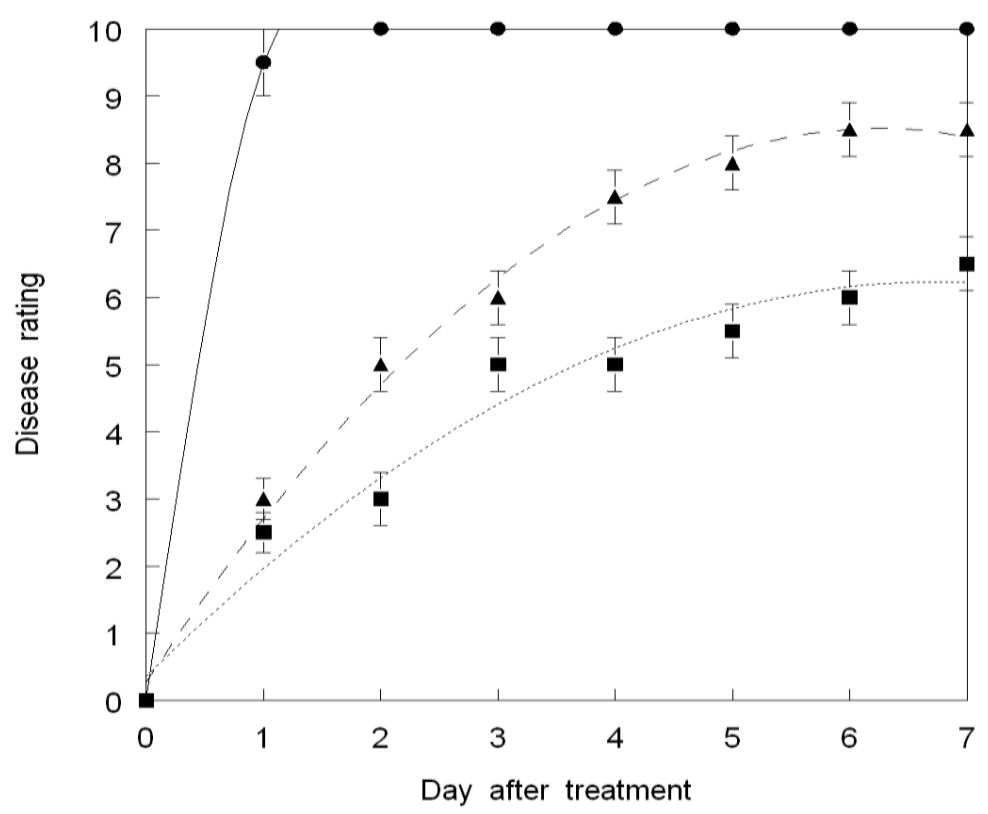

In field experiments, some pathogenesis and mortality of hemp sesbania occurred at all plant growth stages and inoculum concentrations (Figure 3A,B). Generally, M. verrucaria efficacy was higher on smaller plants than larger plants, regardless of inoculum concentration (Figure 3A) with concomitant increases in dry weight reductions as inoculum rates increased (Figure 3B). Lower M. verrucaria concentrations $(0.1 \times$ and $0.5 \times)$ resulted in about $55 \%-70 \%$ mortality in the smallest plants tested $(10-20 \mathrm{~cm})$, but these fungal concentrations provided only $35 \%$ to $50 \%$ mortality in larger (41-60) plants (Figure 3A,B). However, by increasing the inoculum to $1.0 \times$, mortality increased to $95 \%$ in the $21-40 \mathrm{~cm}$ plants and $90 \%$ in the $41-60 \mathrm{~cm}$ plants. Similar trends occurred in the dry weight reduction analyses. 
Disease progression was more rapid with the high $(1.0 \times)$ inoculum rate, with "severe" disease ratings occurring after only 1 day (Figure 4). The comparatively rapid rates of disease development observed in these experiments contrast greatly to disease development observed with some other bioherbicides, such as Colletotrichum gloeosporioides f.sp. aeschynomenee, or C. truncatum, whereas 9 days and 28 days were required to achieve equivalent levels of disease incidance on hemp sesbania in rice and soybean, respectively [38,52]. Season-long control of hemp sesbania was achieved on 10-20 cm plants treated with the high $M$. verrucaria inoculum rates (Figure 5). No visual infection of injury to rice was observed (data not shown). Rice yields were directly proportional to effective hemp sesbania control, and were not significantly different than yields from the acifluorfen-treated plots (Figure 6).

$M$. verrucaria application for biological control of hemp sesbania is decidedly one of the most important factors for consideration of this fungal pathogen as a bioherbicide. Application timing is also important in regard to other bioherbicidal pathogens for various weeds [26-28]. Timing plays a crucial role, both in terms of the growth of the target weed, and in the optimization of environmental conditions present during and after application. In the present studies, the rice plots were under flooded conditions when fungal applications were made, thus optimizing environmental conditions conducive for plant infection, disease development, and weed control. The present studies indicate that applications of $M$. verrucaria to smaller weeds would be most conducive for effective control. The importance of early season control of hemp sesbania in several crops, including rice, soybean, and cotton has been documented $[3,4,6]$. Although smaller plants are more susceptible, it may be possible to improve the efficacy of $M$. verrucaria on older or more mature plants by addition of certain adjuvants, such as unrefined corn oil or invert emulsions [34,38] that can enhance biocontrol efficacy.

Figure 3. Biological control of hemp sesbania at various growth stages in rice field plots using several Myrothecium verrucaria mycelial inoculum concentrations at Stoneville, MS. Acifluorfen was applied post-emergence at $0.56 \mathrm{~kg}_{\text {ai ha }}{ }^{-1} . \mathbf{A}=$ hemp sesbania mortality, and $\mathbf{B}=$ hemp sesbania dry weight reduction. Histogram bar values for each parameter with the same letter are not significantly different at $p=0.05$ using Fisher's least significant difference.
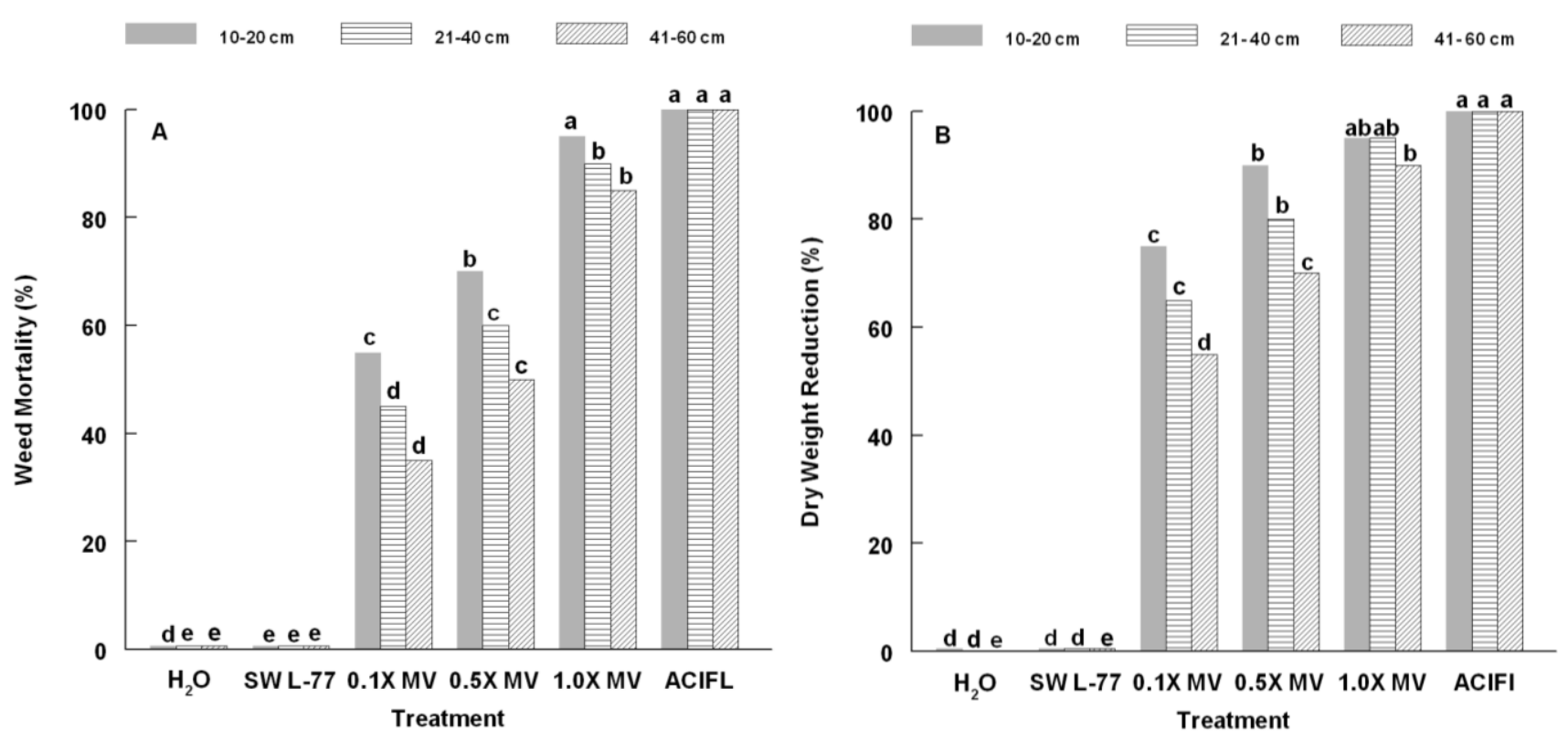
Figure 4. Disease progression on 10-20 cm tall hemp sesbania in rice field plots incited by a Myrothecium verrucaria mycelial formulation. Disease severity was based on a visual rating scale (per plant basis) [50] to estimate disease progression. A rating scale of 0 to 10 was used, as described in the Materials and Methods section. Symptomatology was considered "severe" at ratings of $8-10$. The relationships for $M$. verrucaria disease progression are best described by the equations: $Y=1.10+3.05 X-0.28 X^{2}, R^{2}=0.92$ (solid spheres, solid line) for $M$. verrucaria applied at an inoculum rate of $1.0 \times ; Y=0.44+2.16-0.15 X^{2}, R^{2}=0.98$ (solid triangles, dashed line) for $M$. verrucaria applied at an inoculum rate of $0.5 \times ; Y=0.67+1.06$ $-0.04 X^{2}, R^{2}=0.94$ (solid squares, dotted line) for $M$. verrucaria applied at an inoculum rate of $0.1 \times$. Error bars $= \pm 1$ SEM.

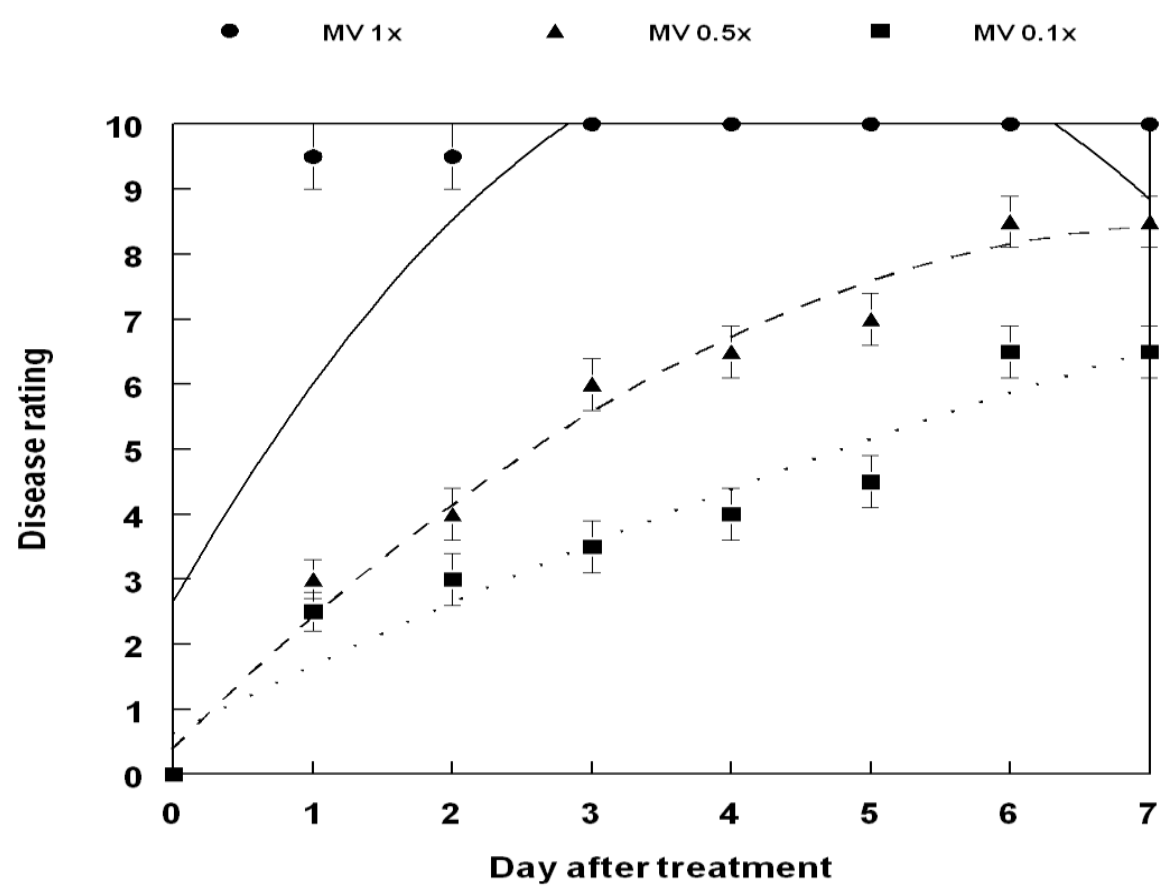

Figure 5. Photograph depicting season-long control of hemp sesbania in rice by a Myrothecium verrucaria mycelial formulation (right), and untreated (left).

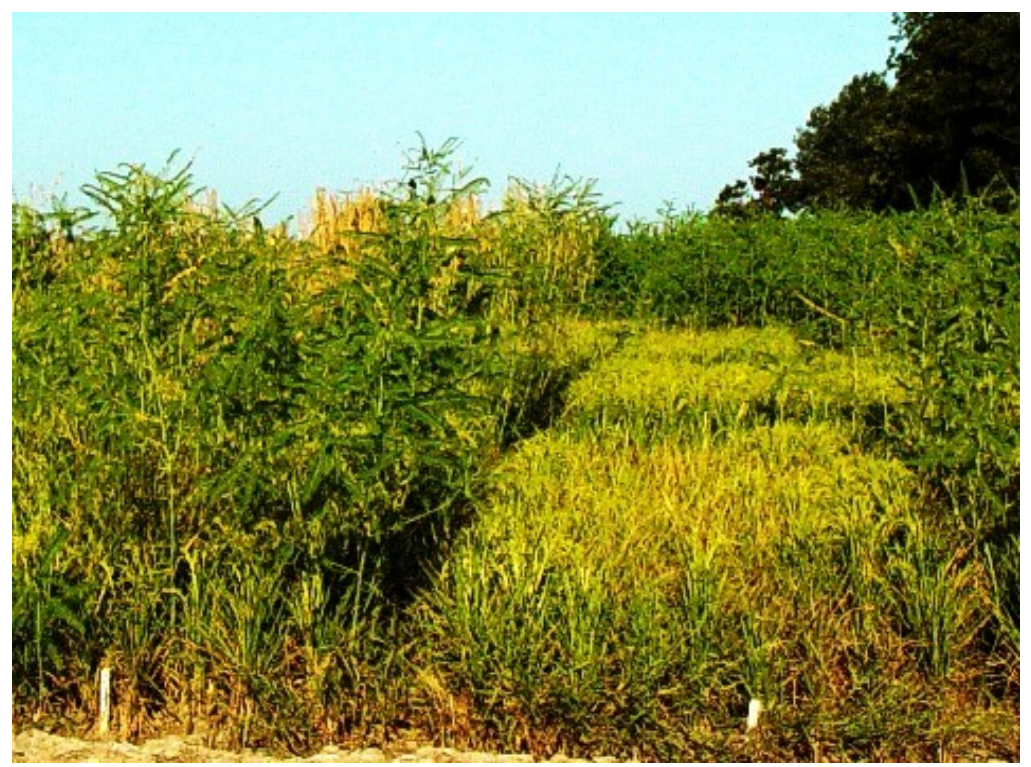


Figure 6. The effects of biological control of hemp sesbania with Myrothecium verrucaria on rice yields, Stoneville, MS. Hemp sesbania mortality data was adapted from Figure 3A for direct data comparison. Yield data were taken (end of season) from plots containing hemp sesbania plants averaging 10-20 cm in height at time of treatment. Histogram bar values for each parameter with the same letter are not significantly different at $p=0.05$ using Fisher's least significant difference.

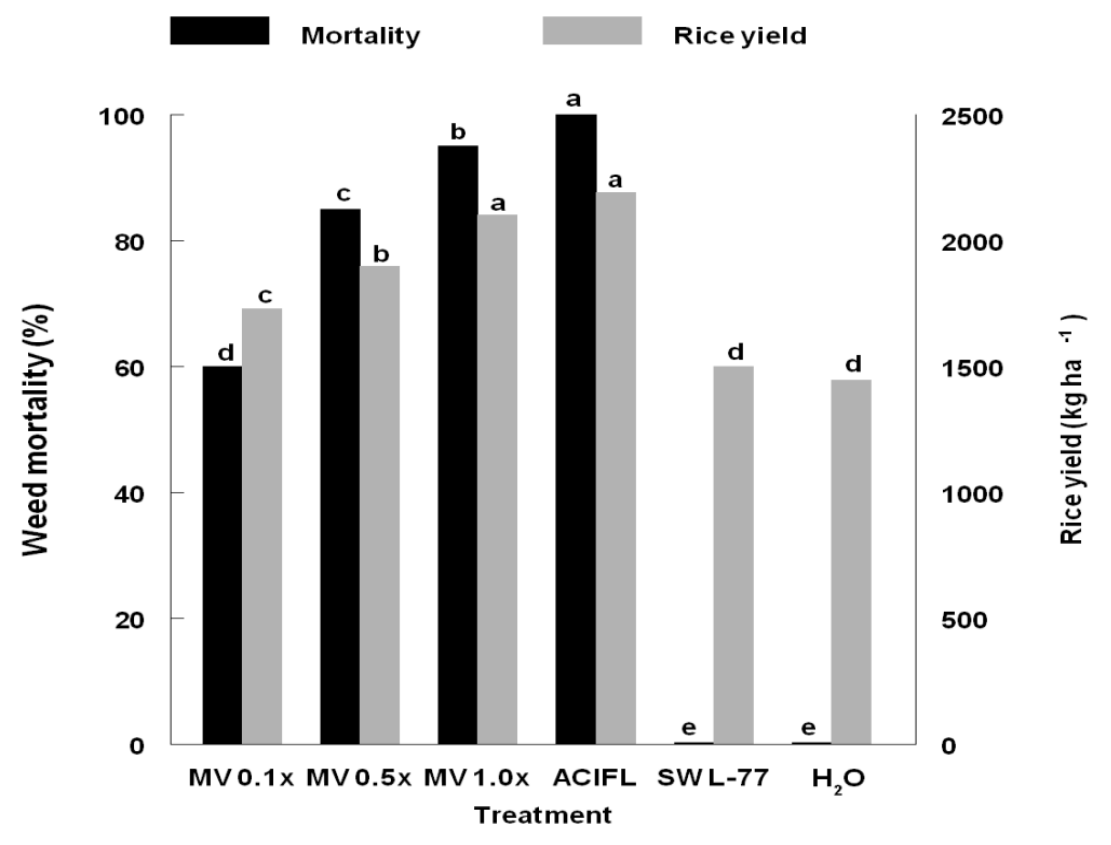

Only a few bioherbicides have been registered worldwide and about 50 have been considered to possess high potential for commercialization [28]. There are many examples of successful uses of plant pathogens for weed control using the classical and bioherbicide approaches as summarized in several reviews e.g., [25-29,31,36]. In most of these reports, the bioherbicidal pathogens exhibited high degrees of host specificity, i.e., they infected and killed only one or a very few species of weeds. This trait is desirable with regard to safety issues such as avoiding infectivity to non-target plants. However in the work presented herein, we have shown that it is possible to use a relatively non-specific plant pathogen to control weeds when the crop is non-susceptible. Furthermore, we have not observed any disease symptoms or injury on susceptible crops (e.g., soybean) in adjacent plots (data not shown).

Biocontrol of weeds with pathogens also has wide interest outside the U.S. For example, researchers in academia, and public and private sectors from 14 European countries plus Israel and Egypt formed a research initiative focusing on biological control of weeds in crops [53]. This research initiative is under the European Co-operation in the Field of Scientific and Technical Research (COST) framework, and targets several major weed species [53-59].

With regard to $M$. verrucaria, many strains produce macrocyclic trichothecene mycotoxins with mammalian toxicity [43], including the isolate (IMI 361390) used in these studies which could pose a safety issue. However, tricothecenes were not detectable in sicklepod plants infected with this strain [60] and only trace amounts of trichothecenes were found in morningglory infected with another $M$. verrucaria strain (ATCC 18398) [61]. Whereas tricothecene content was relatively high in $M$. verrucaria spores, washed spores [62] and fungal mycelial formulations prepared via 
fermentation [48] contained little or no tricothecenes. In the present studies, no injury to rice plants or detrimental effects on rice yield were noted, and analytical tests for tricothecenes in harvested rice grains were not conducted. However, such studies should be performed in the future to assure food safety.

M. verrucaria IMI 361690 has several characteristics that make it desirable for use as a bioherbicide. Although most strains or isolates of $M$. verrucaria are weakly virulent pathogens [63-65], virulence can be influenced by manipulation of inoculum concentrations [39,41,65], and use of adjuvants, such as surfactants $[39,41,48,65,66]$.

In recent years, the Clearfield ${ }^{\mathrm{TM}}$ system has become the predominant rice production system in the mid-south rice producing states of Arkansas, Louisiana, Mississippi, and Missouri [67]. The rice varieties utilized in the Clearfield ${ }^{\mathrm{TM}}$ system are natural mutants with tolerance to the herbicide imazethapyr (Newpath ${ }^{\mathrm{TM}}$ ). Although this herbicide controls many grassy and broadleaf weeds, it fails to control some weeds, especially hemp sesbania, which can result in tremendous weed infestations if other weed control measures are not utilized [68]. Furthermore, the increased use of glyphosate on glyphosate-resistant crops [69] plus the fact that hemp sesbania has a degree of inherent tolerance to this herbicide [16-18] may suggest high potential for a herbicide resistance problem in the future. Lack of effective hemp sesbania control creates a significant need for an effective weed control agent, such as $M$. verrucaria, for this troublesome weed. Future research will focus on applications of $M$. verrucaria formulations to evaluate hemp sesbania control in commercial rice fields.

\section{Conclusions}

M. verrucaria IMI 361690 mycelium is highly effective for biological control of hemp sesbania in rice. The mycelium can be rapidly produced on readily-available, inexpensive agricultural products, such as soy flour and corn meal. Weeds even larger than $60 \mathrm{~cm}$ in height were effectively controlled by using inoculum concentrations of $50 \mathrm{~g} \mathrm{~L}^{-1}$ dry equivalent rates. No visual infection or injury to rice was observed, and levels of weed control and rice yields from plots where weeds were effectively controlled were similar to those that occurred in acifluorfen-treated plots. It is also noteworthy that this research study is one of the few demonstrating an increase in rice yield achieved with a bioherbicide. Rapid infection and mortality caused by $M$. verrucaria suggests the role of possible phytotoxin(s). More research is required to elucidate the intricacies of the infection processes.

These results suggest that a mycelial formulation of $M$. verrucaria has potential as a bioherbicide for controlling hemp sesbania in rice.

\section{Acknowledgments}

The authors thank Terry Newton and Eric Smith for valuable technical assistance.

\section{Conflicts of Interest}

The authors declare no conflict of interest. 


\section{References}

1. Woon, C.K. Effect of two row spacings and hemp sesbania competition on sunflower. J. Agron. Crop Sci. 1987, 159, 15-20.

2. Poisonous Plants of the Southern United States; Bulletin No. 818; Agricultural Extension Service, University of Tennessee: Knoxville, TN, USA, 1980; p. 12.

3. Dowler, C.C. Weed survey-Southern states. Proc. South. Weed Sci. Soc. 1992, 45, 392-407.

4. Lorenzi, H.J.; Jeffery, L.S. Weeds of the United States and Their Control; Van Nostrand Reinhold: New York, NY, USA, 1987.

5. Lovelace, M.L.; Oliver, L.R. Effects of interference and tillage on hemp sesbania and pitted morningglory emergence and seed production. Proc. South. Weed Sci. Soc. 2000, 53, 202.

6. King, C.A.; Purcell, L.C. Interference between hemp sesbania (Sesbania exaltata) and soybean (Glycine max) in response to irrigation and nitrogen. Weed Sci. 1997, 45, 91-97.

7. Norsworthy, J.K.; Oliver, L.R. Hemp sesbania interference in drill-seeded glyphosate-resistant soybean. Weed Sci. 2000, 50, 34-41.

8. Everest, J.W.; Powe, T.A., Jr.; Freeman, J.D. Sesbania. In Poisonous Plants of the Southeastern United States; Alabama Cooperative Extension System [ACES] Publications: Auburn, AL, USA, 2010. Available online: http://www.aces.edu/pubs/docs/A/ANR-0975/ (accessed on 17 August 2013).

9. Bar, A.R.; Baggie, I.; Sanginga, N. The use of Sesbania (Sesbania rostrata) and urea in lowland rice production in Sierra Leone. Agrofor. Syst. 2000, 48, 111-118.

10. Herrera, W.T.; Garrity, D.P.; Vejpas, C. Management of Sesbania rostrata green manure crops grown prior to rain-fed lowland rice on sandy soils. Field Crops Res. 1997, 49, 259-268.

11. Shaw, D.R.; Arnold, J.C. Weed control from herbicide combinations with glyphosate. Weed Technol. 2002, 16, 1-6.

12. Vidrine, P.R.; Reynolds, D.B.; Griffin, J.L. Postemergence hemp sesbania (Sesbania exaltata) control in soybean (Glycine max). Weed Technol. 1992, 6, 374-377.

13. Norris, J.L.; Shaw, D.R.; Snipes, C.E. Weed control from herbicide combinations with three formulations of glyphosate. Weed Technol. 2001, 15, 552-558.

14. Pellerin, K.J.; Webster, E.P.; Zhang, W.; Blouin, D.C. Herbicide mixtures in water-seeded imidazolinone-resistant rice (Oryza sativa). Weed Technol. 2003, 17, 836-841.

15. Pellerin, K.J.; Webster, E.P.; Zhang, W.; Blouin, D.C. Potential use of imazethapyr mixtures in drill-seeded imidazolinone-resistant rice. Weed Technol. 2004, 18, 1037-1042.

16. Jordan, D.L.; York, A.C.; Griffin, J.L.; Clay, P.A.; Vidrine, P.R.; Reynolds, D.B. Influence of application variables of efficacy on glyphosate. Weed Technol. 1997, 11, 354-362.

17. Lich, J.M.; Renner, K.A.; Penner, D. Interaction of glyphosate with postemergence soybean (Glycine max) herbicides. Weed Sci. 1997, 45, 12-21.

18. Oliver, L.R.; Taylor, S.E.; Gander, J.R. Influence of application timing and rate of glyphosate on weed control in soybean. Proc. South. Weed Sci. Soc. 1996, 49, 57.

19. LaMastus, F.E.; Shaw, D.R.; Smith, M.C. Influence of application timing and rate on weed control in Roundup-Ready soybean. Proc. South. Weed Sci. Soc. 1998, 51, 8. 
20. Miller, D.K.; Milligan, J.L.; Wilson, C.F. Evaluation of reduced rate preemergence herbicides in Roundup-Ready soybean. Proc. South. Weed Sci. Soc. 1998, 51, 271-272.

21. Vidrine, P.R.; Griffin, J.L.; Jordan, D.L.; Miller, D.K. Postemergence weed control in soybeans utilizing glyphosate and chlorimuron. Proc. South. Weed Sci. Soc. 1997, 50, 175.

22. Ellis, J.M.; Griffin, J.L. Benefits of soil-applied herbicides in glyphosate-resistant soybean (Glycine max). Weed Technol. 2002, 16, 541-547.

23. Common and chemical names of herbicides approved by the Weed Science Society of America. Weed Sci. 2010, 58, 511-518.

24. Hallett, S.G. Where are the bioherbicides? Weed Sci. 2005, 53, 404-415.

25. Rosskopf, E.N.; Charudattan, R.; Kadir, J.B. Use of Plant Pathogens in Weed Control. In Handbook of Biological Control; Bellows, T.S., Fisher, T.W., Eds.; Academic Press: New York, NY, USA, 1999; pp. 891-918.

26. Charudattan, R. Biological control of weeds by means of plant pathogens: Significance for integrated weed management in modern agro-ecology. BioControl 2001, 46, 229-260.

27. Charudattan, R. Ecological, practical, and political inputs into selection of weed targets: What makes a good biological control target? Biol. Control. 2005, 35, 183-196.

28. Weaver, M.A.; Lyn, M.E.; Boyette, C.D.; Hoagland, R.E. Bioherbicides for Weed Control. In Non-Chemical Weed Management; Updhyaya, M.K., Blackshaw, R.E, Eds.; CABI, International: Cambridge, MA, USA, 2007; pp. 93-110.

29. Hoagland, R.E. Microbes and Microbial Products as Herbicides; American Chemical Society: Washington, DC, USA, 1990.

30. Boyette, C.D.; Abbas, H.K. Host range alteration of the bioherbicidal fungus Alternaria crassa with fruit pectin and plant filtrates. Weed Sci. 1994, 42, 487-491.

31. Boyette, C.D. Host range and virulence of Colletotrichum truncatum, a potential mycoherbicide for hemp sesbania (Sesbania exaltata). Plant Dis. 1991, 75, 62-64.

32. Boyette, C.D.; Quimby, P.C., Jr.; Bryson, C.T.; Egley, G.H.; Fulgham, F.E. Biological control of hemp sesbania (Sesbania exaltata) under field conditions with Colletotrichum truncatum formulated in an invert emulsion. Weed Sci. 1993, 41, 497-500.

33. Abbas, H.K.; Boyette, C.D. Solid substrate formulation of the mycoherbicide Colletotrichum truncatum for hemp sesbania (Sesbania exaltata) control. Biocontrol Sci. Technol. 2000, 10, 297-304.

34. Boyette, C.D.; Hoagland, R.E.; Weaver, M.A. Biocontrol efficacy of Colletotrichum truncatum for hemp sesbania (Sesbania exaltata) control is enhanced with unrefined corn oil and surfactants. Weed Biol. Manag. 2007, 7, 70-76.

35. Cartwright, K.; Boyette, D.; Roberts, M. Lockdown: Collego bioherbicide gets a second act. Phytopathology 2010, 100, S162.

36. Templeton, G.E.; Smith, R.J., Jr.; TeBeest, D.O. Perspectives on mycoherbicides two decades after discovery of the Collego pathogen. In Proceedings of the VII International Symposium on the Biological Control of Weeds, Rome, Italy, 6-11 March 1988; pp. 553-558.

37. Boyette, C.D.; Bowling, A.J.; Vaughn, K.C.; Hoagland, R.E.; Stetina, K.C. Induction of infection of Sesbania exaltata by Colletotrichum gloeosporioides f. sp. aeschynomene formulated in an invert emulsion. World J. Microbiol. Biotechnol. 2010, 26, 951-956. 
38. Boyette, C.D.; Gealy, D.; Hoagland, R.E.; Vaughn, K.C.; Bowling, A.J. Hemp sesbania (Sesbania exaltata) control in rice (Oryza sativa) with the bioherbicidal fungus Colletotrichum gloeosporioides f. sp. aeschynomene formulated in an invert emulsion. Biocontrol Sci. Technol. 2011, 21, 1399-1407.

39. Boyette, C.D.; Walker, H.L.; Abbas, H.K. Biological control of kudzu (Pueraria lobata) with an isolate of Myrothecium verrucaria. Biocontrol Sci. Technol. 2002, 12, 75-82.

40. Hoagland, R.E.; McCallister, T.S.; Boyette, C.D.; Weaver, M.A.; Beecham, R.V. Effects of Myrothecium verrucaria on morning-glory (Ipomoea) species. Allelopath. J. 2011, 27, 151-162.

41. Walker, H.L.; Tilley, A.M. Evaluation of an isolate of Myrothecium verrucaria from sicklepod (Senna obtusifolia) as a potential mycoherbicide agent. Biol. Control 1997, 10, 104-112.

42. Anderson, K.I.; Hallett, S.G. Bioherbicidal spectrum and activity of Myrothecium verrucaria. Weed Sci. 2004, 22, 623-627.

43. Abbas, H.K.; Johnson, B.J.; Shier, W.T.; Tak, H.; Jarvis, B.B.; Boyette, C.D. Phytotoxicity and mammalian cytotoxicity of macrocyclic trichothecenes from Myrothecium verrucaria. Phytochemistry 2002, 59, 309-313.

44. Conway, K.E. Evaluation of Cercospora rodmanii as a biological control of water hyacinth. Phytopathology 1976, 66, 914-917.

45. Boyette, C.D.; Weidemann, G.J.; TeBeest, D.O.; Quimby, P.C., Jr. Biological control of jimsonweed (Datura stramonium) with Alternaria crassa. Weed Sci. 1991, 39, 673-667.

46. Ghorboni, R.; Seel, W.; Litterick, A.; Leifert, C. Evaluation of Alternaria alternata for biological control of Amaranthus retroflexus. Weed Sci. 2000, 48, 474-480.

47. Elzein, A.; Kroschel, J. Fusarium oxysporum Foxy 2 shows potential to control both Striga heronthica and S. asiatica. Weed Res. 2004, 44, 433-438.

48. Boyette, C.D.; Weaver, M.A.; Hoagland, R.E.; Stetina, K.C. Submerged culture of a mycelial formulation of a bioherbicidal strain of Myrothecium verrucaria with mitigated mycotoxin production. World J. Microbiol. Biotechnol. 2008, 24, 2721-2726.

49. Tuite, J. Plant Pathological Methods: Fungi and Bacteria; Burgess Publication Co.: Minneapolis, MN, USA, 1969.

50. Horsfall, J.G.; Barratt, R.W. An improved grading system for measuring diseases. Phytopathology $\mathbf{1 9 4 5 ,} 35,655$.

51. Steele, R.G.D.; Torrey, J.H.; Dickeys, D.A. Multiple Comparisons. In Principles and Procedures of Statistics - A Biometrical Approach; McGraw Hill: New York, NY, USA, 1997; p. 365.

52. Boyette, C.D.; Hoagland, R.E. Biological Control of Hemp sesbania (Sesbania exaltata) and sicklepod (Senna obtusifolia) in soybean with anthracnose pathogen mixtures. Weed Technol. 2010, 24, 551-556.

53. Müller-Schärer, H. Finding solutions for biological control of weeds in European crop systems. BioControl 2001, 46, 125-126.

54. Amsellem, Z.; Barghouthi, S.; Cohen, B.; Goldwasser, Y.; Gressel, J.; Hornok, L.; Kerenyi, A.; Kleifeld, Y.; Klein, O.; Kroschel, J.; et al. Recent advances in the biocontrol of Orobanche (broomrape) species. BioControl 2001, 46, 211-228. 
55. Bürki, H.M.; Lawrie, J.; Greaves, M.P.; Down, V.M.; Jüttersonke, B.; Cagán, L.; Vráblová, V.; Ghorbani, R.; Hassan, E.A.; Schroeder, D. Biocontrol of Amaranthus spp. in Europe: State of the art. BioControl 2001, 46, 197-210.

56. Défago, G.; Ammon, H.U.L.; Cagán, B.; Draeger, B.; Greaves, M.P.; Guntli, D.; Hoeke, D.; Klimes, L.; Lawrie, J.; Moënne-Loccoz, Y.; et al. Towards the biocontrol of bindweeds with a mycoherbicide. BioControl 2001, 46, 157-173.

57. Frantzen, J.; Paul, N.D.; Müller-Schärer, H. The system management approach of biological weed control: Some theoretical considerations and aspects of application. BioControl 2001, 46, 139-155.

58. Netland, J.; Dutton, L.C.; Greaves, M.P.; Baldwin, M.; Vurro, M.; Evidente, J.; Einhorn, G.; Scheepens, P.C.; French, L.W. Biological control of Chenopodium album L. in Europe. BioControl 2001, 46, 175-196.

59. Scheepens, P.C.; Müller-Schärer, H.; Kempenaar, C. Opportunities for biological weed control in Europe. BioControl 2001, 46, 127-138.

60. Abbas, H.K.; Tak, H.; Boyette, C.D.; Shier, W.T.; B.B. Jarvis. Macrocyclic trichothecenes are undetectable in kudzu (Pueraria montana) plants treated with a high-producing isolate of Myrothecium verrucaria. Phytochemistry 2001, 58, 269-276.

61. Milhollon, R.W.; Berner, D.K.; Paxson, L.K.; Jarvis, B.B.; Bean, G.W. Myrothecium verrucaria for control of annual morningglories in sugarcane. Weed Technol. 2003, 17, 276-283.

62. Weaver, M.A.; Boyette, C.D.; Hoagland, R.E. Bioherbicidal activity from washed spores of Myrothecium verrucaria. World J. Microbiol. Biotechnol. 2012, 28, 1941-1946.

63. Domsch, K.H.; Gams, W.; Anderson, T.H. Myrothecium. In Compendium of Soil Fungi; Academic Press: New York, NY, USA, 1980; pp. 481-487.

64. Nguyen, T.H.; Mathur, S.B.; Neergaard, P. Seed-borne species of Myrothecium and their pathogenic potential. Trans. Br. Mycol. Soc. 1973, 61, 347-354.

65. Yang, S.; Jong, S. C. Host range determination of Myrothecium verrucaria isolated from leafy spurge. Plant Dis. 1995, 79, 994-997.

66. Weaver, M.A.; Jin, X.; Hoagland, R.E.; Boyette, C.D. Improved bioherbicidal efficacy by Myrothecium verrucaria via spray adjuvants or herbicide mixtures. Biol. Control 2009, 50, $150-156$.

67. Shivrain, V.K.; Burgos, N.R.; Moldenhauer, K.A.K.; McNew, R.W.; Baldwin, T.L. Characterization of spontaneous crosses between Clearfield rice (Oryza sativa) and red rice (Oryza sativa). Weed Technol. 2006, 20, 576-584.

68. Scott, R.C.; Meins, K.B.; Smith, K.L. Tank-mix partners with Newpath herbicide for hemp sesbania control in a Clearfield rice-production system. Ark. Agric. Res. Ser. 2005, 54, 225-229.

69. Powles, S.B. Evolved glyphosate-resistant weeds around the world: Lessons to be learnt. Pest Manag. Sci. 2008, 64, 360-365.

(C) 2014 by the authors; licensee MDPI, Basel, Switzerland. This article is an open access article distributed under the terms and conditions of the Creative Commons Attribution license (http://creativecommons.org/licenses/by/3.0/). 